\title{
Verkenning van gezondheidssituatie en gezondheids- verschillen in de Euregio Maas-Rijn (EMR)
}

\author{
Nicole Curvers · Laura Willems · Kevin Konings · Mandy M. N. Stijnen · Maria W. J. Jansen
}

Published online: 16 December 2019

(C) The Author(s) 2019

\begin{abstract}
Samenvatting De Euregio Maas-Rijn (EMR) bestaat uit vijf grensregio's in Nederland, België en Duitsland. Vanwege overeenkomsten als grensligging en een industrieel (mijn)verleden is hun gezondheidssituatie waarschijnlijk vergelijkbaar. Hoe ziet de gezondheidssituatie van de EMR eruit en welke factoren spelen een rol wanneer er toch gezondheidsverschillen blijken te zijn? We hebben een mixed method study uitgevoerd, waarbij we gebruikmaakten van een unieke Euregionale dataset met gegevens over aantal inwoners, geslacht, leeftijd, opleiding, werk, levensverwachting bij geboorte, mortaliteit, doodsoorzaken en overgewicht/ obesitas. We hebben semigestructureerde interviews afgenomen bij 22 deskundigen uit de publieke gezondheidszorg en aanverwante beleidsterreinen, allen werkzaam binnen de EMR. Vooral de levensverwachting bij geboorte blijkt te verschillen: inwoners van de Provincie Limburg (B) leven gemiddeld 2,7 jaar langer dan de inwoners van de Provincie Luik (B) (82,5 jaar versus 79,9 jaar). Volgens stakeholders kunnen sociaal-culturele en sociaaleconomische factoren (zoals grensbarrières, een lage sociaaleconomische status) de gezondheidsverschillen binnen de EMR verklaren. De gezondheidssituatie in de EMR kan verbeterd worden door inzet op integraal beleid en het versterken van gezondheidsvaardigheden bij de lage SES-populatie.
\end{abstract}

\footnotetext{
N. Curvers, MSc. $(\bowtie) \cdot$ L. Willems $\cdot$ K. Konings, MSc. ·

Dr. M. M. N. Stijnen

Afdeling Kennis \& Innovatie, GGD Zuid Limburg, Heerlen,

Nederland

nicole.curvers@ggdzl.nl

Prof.dr.ir. M. W. J. Jansen

Academische Werkplaats Publieke Gezondheid, GGD Zuid

Limburg, Universiteit Maastricht, Maastricht, Nederland
}

Trefwoorden Euregio Maas-Rijn (EMR) • gezondheidssituatie - levensverwachting • mortaliteit · grensbarrières · gezondheidsverschillen

Abstract The Euregion Meuse-Rhine (EMR) consists of five border regions in the Netherlands, Belgium and Germany. Expected is that these regions have a similar health status given the fact that they are all border regions and share an industrial (mining) history. What is the health status of the EMR, and which factors play a role if there are health differences in the EMR? A mixed method study was carried out. A unique Euregional dataset was used with data on number of citizens, gender, age, education, work, life expectancy, mortality, and overweight/ obesity. Semi-structured interviews were conducted with 22 experts working within the EMR in the field of public health and related policy areas. Most notable differences were found for life expectancy at birth: citizens of the Province of Limburg (B) live on average 2.7 years longer than those of the Province of Liège (B) (82.5 years versus 79.9 years). According to stakeholders, socio-cultural and socioeconomic factors (such

\section{Kernpunten}

- Dit onderzoek toont aan dat er verschillen zijn in de gezondheidssituatie tussen de EMR-regio's.

- De stakeholders benoemen gemeenschappelijke factoren die ten grondslag liggen aan de gezondheidssituatie in de EMR: het mijnverleden, lage SES en grensbarrières.

- Investeren in Euregionale samenwerking op het gebied van dataverzameling is nodig om een rijkere dataset voor grensoverschrijdende vergelijking van de gezondheidssituatie mogelijk te maken. 
as border barriers, low SES) can explain perceived health inequalities. The health status of the EMR can be improved by focusing on Health in All Policies and strengthening health literacy.

Keywords Euregion Meuse-Rhine (EMR) - Health status - Life expectancy · Mortality - Border barriers . Health inequalities

\section{Inleiding}

De levensverwachting van de Nederlandse bevolking neemt toe. Tegelijkertijd behoudt Limburg, en met name de regio Zuid-Limburg, een gezondheidsachterstand ten opzichte van de rest van Nederland. In het onderzoeksrapport 'Op zoek naar de Limburg-factor' is gekeken naar factoren die deze gezondheidsachterstand kunnen verklaren. Zo wordt de unieke ligging van Zuid-Limburg (zie fig. 1) genoemd als een mogelijke factor van invloed [1]. Van de Zuid-Limburgse regiogrenzen grenst $97 \%$ aan buurlanden. De regio's Zuid-Limburg (NL), Regio Aken (D), de Vlaamse Provincie Limburg (B), de Waalse Provincie Luik (B) en Oost-België (Duitstalige Gemeenschap) (B) vormen samen de Euregio Maas-Rijn (EMR). Overeenkomsten tussen de EMR-regio's, zoals de ligging aan de grens, de historie en een industrieel (mijn)verleden (zie fig. 2) doen vermoeden dat de gezondheidssituatie van deze regio's vergelijkbaar is. Tot op heden is hier echter nog geen onderzoek naar gedaan.

De centrale onderzoeksvraag luidt: hoe ziet de gezondheidssituatie van de EMR eruit en welke factoren spelen een rol als er sprake is van gezondheidsverschillen in de EMR?

\section{Methode}

\section{Onderzoeksopzet}

Dit onderzoek betreft een mixed method study en maakt gebruik van een concurrent triangulation design [2]. De kwantitatieve en kwalitatieve gegevens zijn tegelijkertijd verzameld en geanalyseerd, en hebben gelijkwaardige prioriteit. De kwantitatieve data zijn gebruikt om de gezondheidssituatie in de EMR in kaart te brengen. Met het kwalitatieve onderzoek is gereflecteerd op de gezondheidsverschillen. De resultaten van beide methoden worden geïntegreerd in de interpretatiefase van het onderzoek $[2,3]$.

\section{Dataregisters}

Om inzicht te krijgen in de gezondheidssituatie van de grensregio's is het belangrijk dat de data onderling vergelijkbaar zijn. Daarvoor is gebruikgemaakt van de resultaten van het project 'Data in de EMR' waarin euPrevent|EMR, de GGD Zuid Limburg en het Centraal Bureau voor de Statistiek (CBS) samenwerken. Dit project had als doel om gezondheidsdata van de EMR-regio's beschikbaar en vergelijkbaar te maken [4]. Dit resulteerde in een eerste set van indicatoren, bestaande uit registerdata over aantal inwoners, geslacht, leeftijd, opleiding, werk, levensverwachting, mortaliteit en doodsoorzaken (2014). Daarnaast is voor de indicator overgewicht (BMI) gebruikgemaakt van surveydata uit de GGD Gezondheidsmonitor uit Nederland (2012), de Mikrosenzus uit Duitsland (2013) en de Gezondheidsenquête uit België (2013).
Figuur 1 De regio's van de Euregio Maas-Rijn

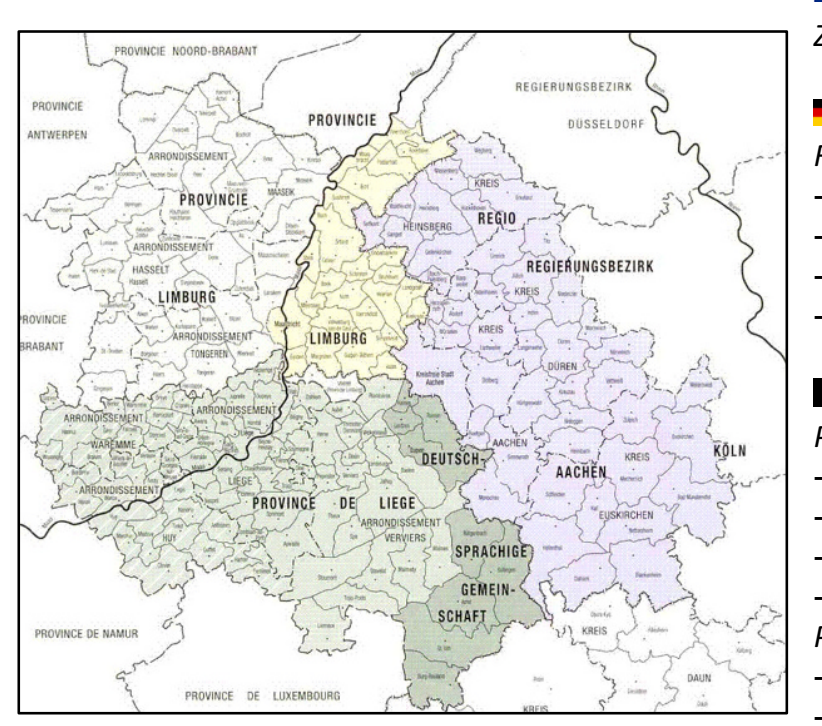

Nederland (NL)

Zuid-Limburg

Regio Aken

- $\quad$ Stadtregion Aachen

Kreis Heinsberg

Kreis Düren

Kreis Euskirchen

Delgië (B)

Provincie Luik

- $\quad$ Arrondissement Luik

Arrondissement Verviers

Arrondissement Hoei

Arrondissement Borgworm

Provincie Limburg

Arrondissement Hasselt

Arrondissement Tongeren

Arrondissement Maaseik

Oost-België/Duitstalige

Gemeenschap (onderdeel van

arrondissement Verviers) 


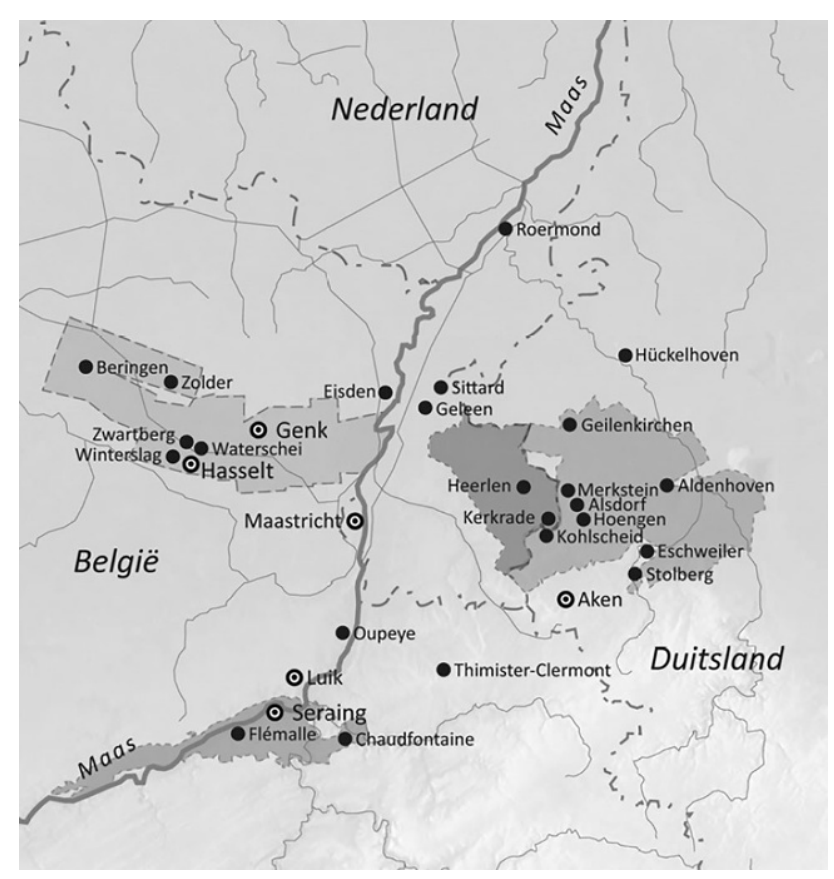

Figuur 2 De voormalige mijngebieden in de Euregio MaasRijn

Voor dit artikel zijn de cijfers beperkt tot op EMRniveau. Vanwege een gebrek aan voldoende gegevens zijn de data van de EMR-regio Oost-België opgenomen in het arrondissement Verviers, Provincie Luik (B), waar de regio als gerechtelijk arrondissement onderdeel van uitmaakt. Om de gezondheidssituatie van de EMR-regio's beter te kunnen interpreteren, wordt voor enkele indicatoren verwezen naar de data op kleinere schaal (arrondissementen en Kreise). Een uitgebreid overzicht van al deze cijfers valt buiten de strekking van dit artikel en is te raadplegen in het rapport 'Op zoek naar de Euregio-factor' [5].

\section{Toelichting op indicatoren in de Euregionale dataset}

Om een eenduidige vergelijking van de grensregio's mogelijk te maken hebben we internationale definities gehanteerd. Voor het vaststellen van het aantal werklozen is uitgegaan van de definitie van de International Labour Organization (ILO): een werkloze is iemand tussen de 15 en 65 jaar die niet werkt, wel onmiddellijk beschikbaar is voor een passende betrekking en er actief naar zoekt (met uitzondering van studenten) [6].

Bij het vergelijken van het opleidingsniveau is gebruikgemaakt van de internationale onderwijsindeling ISCED2011. Deze maakt onderscheid tussen laag, midden en hoog. Toegepast op het Nederlandse onderwijssysteem betekent deze categorisering dat een laag opleidingsniveau vergelijkbaar is met geen onderwijs, primair onderwijs of vmbo. Een midden opleidingsniveau is vergelijkbaar met havo, vwo en mbo. Een hoog opleidingsniveau is vergelijkbaar met hbo en universitaire scholing [7].
Voor het classificeren van de doodsoorzaken is gebruikgemaakt van de 'International Classification of Diseases and Related Health Problems' (ICD-10) [8]. De mortaliteitscijfers naar aandoening zijn berekend per duizend inwoners en betreffen de meest voorkomende doodsoorzaken: zuigelingensterfte, uitwendige doodsoorzaken, natuurlijke doodsoorzaken, kanker, hart- en vaatziekten, en longziekten. Zuigelingensterfte is in dit onderzoek vastgesteld als overlijden binnen het eerste levensjaar.

De indicator levensverwachting bij geboorte is voor alle regio's met behulp van ruwe registerdata berekend door toepassing van de sullivanmethode. Deze methode maakt voor de berekening gebruik van sterftecijfers en prevalenties naar leeftijd [9]. Levensverwachting bij geboorte wordt veel gebruikt als indicator voor de gezondheidstoestand van de bevolking [9].

\section{Selectie van stakeholders voor de interviews}

In totaal zijn zeventien semigestructureerde interviews afgenomen met 22 stakeholders (bij vijf interviews waren twee stakeholders aanwezig). Doelgerichte selectie van stakeholders vond plaats op basis van hun huidige werkzaamheden en/of kennis/ expertise op het gebied van de gezondheidssituatie binnen een EMR-regio [3]. De stakeholders werden geselecteerd via het Euregionale netwerk van euPrevent|EMR. De stakeholders werden per e-mail benaderd voor deelname; allen stemden hiermee in.

De 22 stakeholders waren deskundigen uit de publieke gezondheidssector en aanverwante beleidsterreinen. Deze stakeholders waren onder andere werkzaam voor de publieke gezondheidsdienst in hun regio: de GGD (NL), het Gesundheidsamt (D), LOGO (B), Observatoire de la Santé (B) en euPrevent|EMR. Daarnaast zijn stakeholders benaderd om vanuit hun vakgebieden een blik te werpen op de gezondheidssituatie in de EMR. Er is gesproken met experts in gezondheids- en doodsoorzakenstatistiek, en met experts met een achtergrond in de sociologie, geschiedenis en cultuur.

De functies van de stakeholders waren onderzoeker/epidemioloog $(n=7)$, beleidsmedewerker/ coördinator $(n=4)$, afdelingshoofd $(n=3)$ of directeur $(n=7)$, of provinciaal gedeputeerde (NL) $(n=1)$. De verhouding man $(n=11)$ en vrouw $(n=11)$ was gelijk.

\section{Afname van de interviews}

Een week voorafgaande aan het interview ontvingen de geïnterviewden de topiclijst. De onderwerpen betroffen de regionale en Euregionale gezondheidssituatie, de invloed van (omgevings)factoren en de mogelijkheden tot gezondheidsverbetering.

De interviews vonden plaats in de periode van juli 2017 tot en met oktober 2017. Vijftien interviews vonden face-to-face plaats op verschillende locaties en 
twee telefonisch (vanwege de afstand). De interviews duurden tussen de 60 en 90 minuten. Bij de interviews met Duitse en Franse stakeholders werden de vragen in het Engels gesteld en beantwoord in het Engels of Duits. Twee onderzoekers (LW en NC) waren aanwezig bij de uitvoering van alle interviews.

De interviews zijn opgenomen, door een van de onderzoekers (NC) getranscribeerd, volledig uitgeschreven en waar nodig aangevuld door een onderzoekspartner (LW). Hoewel letterlijk transcriberen het uitgangspunt was, was dit vanwege de vertaling vanuit het Engels of Duits niet altijd mogelijk. De interviews met niet-Nederlandse stakeholders zijn in het Engels uitgeschreven. Het interviewtranscript werd als member check voorgelegd aan de geïnterviewde. Op deze manier werd de interviewweergave gecontroleerd op juistheid.

\section{Analyse}

De analyse van de kwantitatieve data is uitgevoerd met Excel en SPSS. De indicatoren zijn door de onderzoekers (KK en NC) door middel van beschrijvende statistiek (frequentietabellen) inzichtelijk gemaakt en gesplitst naar EMR-regio.

Bij de kwalitatieve analyse heeft één onderzoeker (LW) alle interviewtranscripten handmatig en thematisch gecodeerd op basis van de thema's uit de topiclijst. Een tweede onderzoeker (NC) heeft een verdiepingsslag aangebracht door alle transcripten en coderingen te bekijken en waar nodig aan te vullen. Bij tegenstrijdige inzichten vond afstemming tussen de onderzoekers plaats en zo nodig werd een derde persoon (MJ) geconsulteerd. Dit proces werd herhaald totdat consensus bereikt was over de definitieve coderingen.

\section{Resultaten}

Tabel 1 bevat de demografische en sociaaleconomische gegevens van de EMR-regio's. Zuid-Limburg is qua oppervlakte het kleinst $\left(660 \mathrm{~km}^{2}\right)$, maar wel het dichtst bevolkt (915 inwoners per $\mathrm{km}^{2}$ ). Daarentegen heeft de Provincie Luik (B) het grootste oppervlak $\left(3.862 \mathrm{~km}^{2}\right)$ en de laagste bevolkingsdichtheid (282 inwoners per $\mathrm{km}^{2}$ ). Zuid-Limburg en de regio Aken (D) kennen het grootste aandeel 65-plussers (respectievelijk $21 \%$ en $20 \%$ ) en zijn daarmee iets sterker vergrijst dan de rest van de EMR. De verschillen in werkloosheidspercentages en opleidingsniveau zijn gering, met uitzondering van de Provincie Luik (B) waar het aandeel werklozen en laagopgeleiden aanzienlijk hoger is (respectievelijk 13\% en 34\%). Dit geldt voor alle vier de arrondissementen binnen de Provincie Luik; in het arrondissement Luik wonen zowel de meeste laagopgeleiden als de meeste werklozen.

\section{Gezondheidssituatie in de EMR}

Tabel 2 bevat de gezondheidsgegevens van de EMR-regio's. Als we de cijfers van de EMR-regio's vergelijken met de gemiddelde gezondheidssituatie in de EMR, dan wijken Zuid-Limburg (NL) en Regio Aken (D) nauwelijks af van het EMR-gemiddelde op de gepresenteerde indicatoren. De cijfers maken duidelijk dat er wel verschillen zijn tussen de EMR-regio's, zoals in levensverwachting bij geboorte (zie fig. 3). De gemiddelde levensverwachting in de EMR is 81 jaar. De inwoners van de Provincie Limburg (B) hebben de hoogste levensverwachting (82,5 jaar) en leven gemiddeld 2,7 jaar langer dan de inwoners van de Provincie Luik (B), die de laagste levensverwachting hebben (79,8 jaar). Als we verder inzoomen op de afzonder-

Tabel 1 Demografische en sociaaleconomische gegevens van de EMR

\begin{tabular}{|c|c|c|c|c|c|}
\hline & $\begin{array}{l}\text { Zuid- } \\
\text { Limburg (NL) }\end{array}$ & $\begin{array}{l}\text { Regio } \\
\text { Aken (D) }\end{array}$ & Provincie Luik (B) & Provincie Limburg (B) & Euregio Maas-Rijn \\
\hline Oppervlakte $\left(\mathrm{km}^{2}\right)^{\mathrm{a}}$ & 660 & 3.525 & 3.862 & 2.422 & 11.323 \\
\hline Aantal inwoners & 604.154 & 1.244 .202 & 1.091 .734 & 856.280 & 3.872 .634 \\
\hline Bevolkingsdichtheid (inwoners per km²) & 915 & 353 & 282 & 354 & 342 \\
\hline \multicolumn{6}{|l|}{ Leeftijdsgroepen } \\
\hline $0-14$ & $13 \%$ & $13 \%$ & $17 \%$ & $16 \%$ & $15 \%$ \\
\hline $15-24$ & $12 \%$ & $12 \%$ & $12 \%$ & $11 \%$ & $12 \%$ \\
\hline $25-44$ & $22 \%$ & $24 \%$ & $26 \%$ & $26 \%$ & $24 \%$ \\
\hline $45-54$ & $16 \%$ & $17 \%$ & $14 \%$ & $16 \%$ & $16 \%$ \\
\hline $55-64$ & $15 \%$ & $14 \%$ & $13 \%$ & $14 \%$ & $14 \%$ \\
\hline $65+$ & $21 \%$ & $20 \%$ & $18 \%$ & $18 \%$ & $19 \%$ \\
\hline Beroepsbevolking & $66 \%$ & $67 \%$ & $65 \%$ & $66 \%$ & $66 \%$ \\
\hline Werkloosheid & $8 \%$ & $6 \%$ & $13 \%$ & $6 \%$ & $8 \%$ \\
\hline \multicolumn{6}{|l|}{ Opleidingsniveau } \\
\hline Laag & $28 \%$ & $21 \%$ & $34 \%$ & $27 \%$ & $28 \%$ \\
\hline Midden & $43 \%$ & $59 \%$ & $36 \%$ & $44 \%$ & $46 \%$ \\
\hline Hoog & $28 \%$ & $20 \%$ & $30 \%$ & $29 \%$ & $27 \%$ \\
\hline
\end{tabular}




\section{Wetenschappelijk artikel}

Tabel 2 Gezondheidssituatie in de EMR; levensverwachting, mortaliteit en BMI

\begin{tabular}{|c|c|c|c|c|c|}
\hline & $\begin{array}{l}\text { Zuid- } \\
\text { Limburg (NL) }\end{array}$ & $\begin{array}{l}\text { Regio } \\
\text { Aken (D) }\end{array}$ & Provincie Luik (B) & Provincie Limburg (B) & Euregio Maas-Rijn \\
\hline Levensverwachting bij geboorte & 81,1 & 80,7 & 79,8 & 82,5 & 81,0 \\
\hline Mortaliteit (per 1.000) & 10,6 & 10,7 & 10,3 & 8,1 & 10,0 \\
\hline Uitwendige doodsoorzaken & 0,4 & 0,3 & 0,8 & 0,5 & 0,5 \\
\hline Natuurlijke doodsoorzaken & 10,2 & 10,4 & 9,6 & 7,6 & 9,5 \\
\hline Kanker & 3,4 & 3,0 & 2,6 & 2,4 & 2,8 \\
\hline Hart- en vaatziekten & 3,0 & 4,0 & 2,9 & 2,3 & 3,1 \\
\hline Longziekten & 0,9 & 0,9 & 1,1 & 0,5 & 0,9 \\
\hline Zuigelingensterfte & 4,0 & 3,0 & 3,3 & 2,7 & 3,3 \\
\hline \multicolumn{6}{|l|}{ BMI volwassenen } \\
\hline Ondergewicht & $1,9 \%$ & $2,4 \%$ & $3,2 \%^{\mathrm{a}}$ & $2,6 \%^{b}$ & c \\
\hline Gezond gewicht & $46,6 \%$ & $46,5 \%$ & $46,6 \%^{a}$ & $49,6 \%^{b}$ & c \\
\hline Overgewicht & $37,3 \%$ & $35,0 \%$ & $34,1 \%^{a}$ & $35,1 \%^{\mathrm{b}}$ & c \\
\hline Obesitas & $14,3 \%$ & $16,2 \%$ & $16,1 \%{ }^{a}$ & $12,6 \%^{b}$ & c \\
\hline Overgewicht en/of obesitas & $51,6 \%$ & $51,1 \%$ & $50,2 \%^{a}$ & $47,7 \%^{b}$ & c \\
\hline
\end{tabular}

lijke regio's, dan wordt duidelijk dat inwoners van het Arrondissement Maaseik (B) (83,3 jaar) 4,4 jaar langer leven dan inwoners uit Arrondissement Hoei (B), die de laagste levensverwachting hebben (78,9 jaar).

Zowel tussen de EMR-regio's als binnen elke EMRregio zijn de verschillen in mortaliteit gering (zie tab. 2 en fig. 4). In de Provincie Limburg (B) zijn de mortaliteitscijfers voor bijna alle onderzochte doodsoorzaken het laagst. De sterfte aan hart- en vaatziekten komt in Regio Aken (D) het meeste voor; Zuid-Limburg springt er in negatieve zin uit vanwege sterfte door kanker en zuigelingensterfte; de sterfte door longziekten is het hoogst in de Provincie Luik (B).

Ruim de helft van de volwassenen in het Nederlandse en Duitse gedeelte van de EMR heeft overgewicht en/of obesitas. In België zijn er geen gegevens beschikbaar voor de Provincie Limburg (B) en de Provincie Luik (B). Wel is bekend dat gemiddeld $48 \%$ van de Vlaamse bevolking en $50 \%$ van de Waalse bevolking overgewicht en/of obesitas heeft. Een vergelijking tussen en binnen de EMR-regio's op deze indicator wordt hierdoor bemoeilijkt.

\section{Gezondheidsverschillen binnen de EMR}

De stakeholders erkennen de aanwezigheid van verschillen in gezondheidssituatie binnen de EMR. Hiervoor noemen ze een aantal, deels generieke factoren die ongeacht de regio gelden, en deels specifieke en voor de regio unieke factoren.
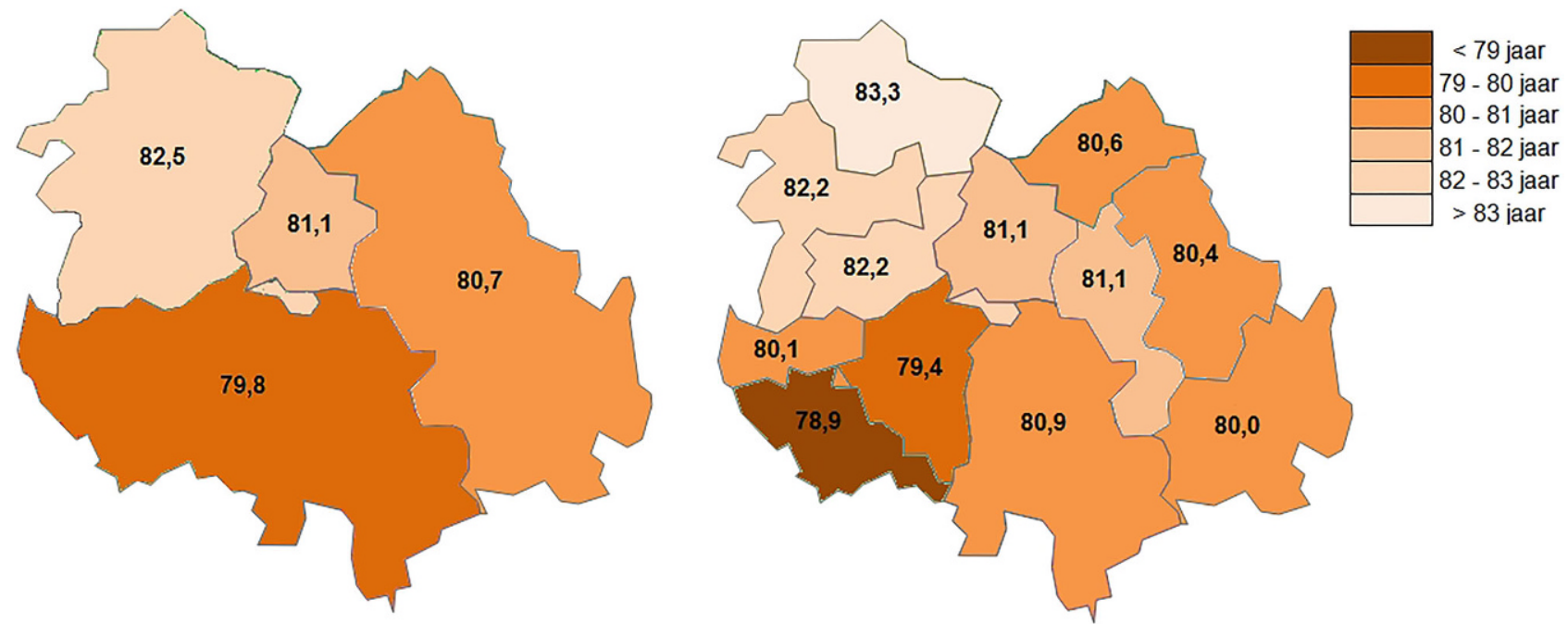

Figuur 3 Levensverwachting bij geboorte, per EMR-regio en ingezoomd per regio 

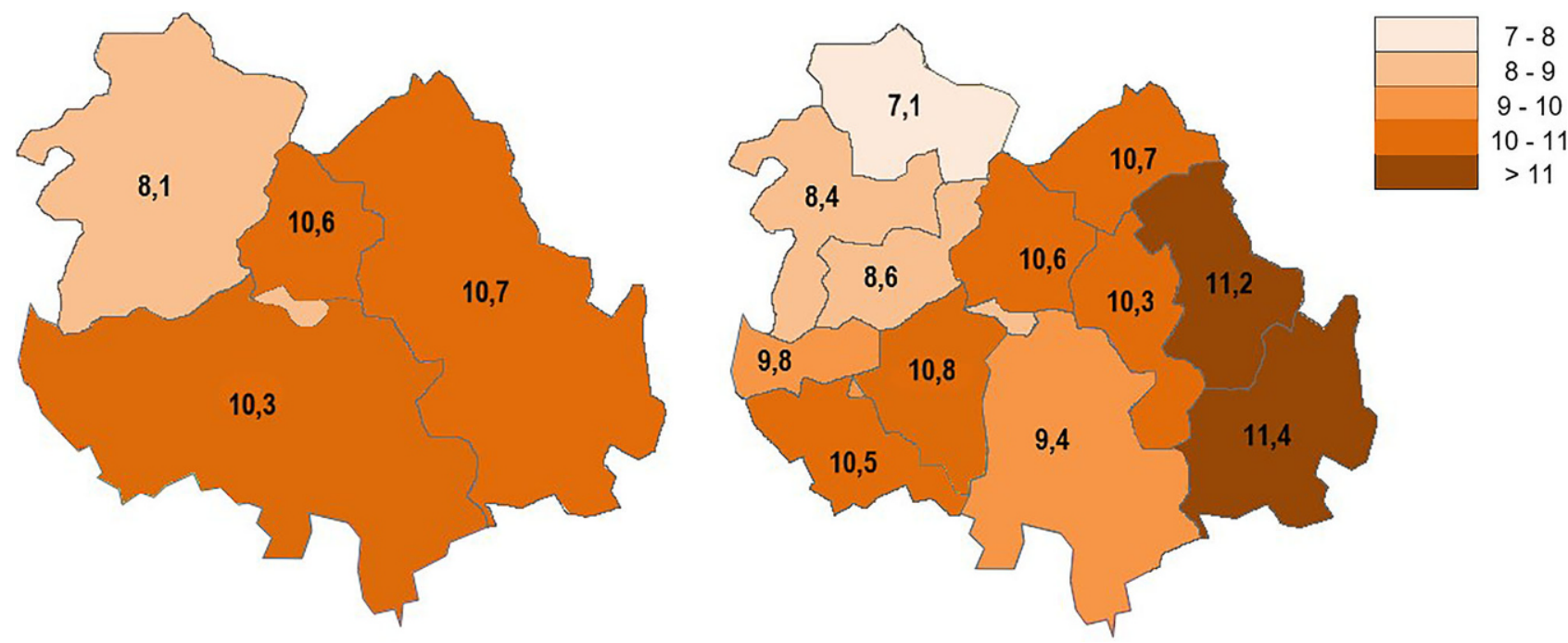

Figuur 4 Mortaliteit per 1.000 inwoners, per EMR-regio en ingezoomd per regio

\section{Vervangende en passende werkgelegenheid}

Stakeholders zien vooral gezondheidsachterstanden in de (voormalige) mijn- en industriegebieden. In deze regio's is de werkloosheid groter en wonen meer mensen met een lager opleidingsniveau en lage sociaaleconomische status (SES). Door het sluiten van industrieën zijn banen weggevallen en het ontbreken van passende vervangende werkgelegenheid in de omgeving heeft geleid tot verhoogde werkloosheid: 'Door de sluiting van een luchthaven in Selfkant gingen duizend deeltijdbanen verloren voor praktisch opgeleide vrouwen. Vervangende werkgelegenheid was er niet voor hen, net zoals dit het geval was bij het sluiten van de mijnbouw.' [stakeholder 1; directeur]

In Zuid-Limburg is weliswaar nieuwe werkgelegenheid gecreëerd door de komst van de universiteit, het $\mathrm{ABP}$ en het CBS, maar hier konden praktisch geschoolde mijnwerkers niet aan de slag. Veel oudmijnwerkers gingen met vervroegd pensioen of werden arbeidsongeschikt verklaard (WAO). Er was veel verborgen werkeloosheid, met sociale ontwrichting tot gevolg. Zowel mannen als vrouwen verloren werk en zaten thuis. Er heerste veel boosheid en verborgen sociale problematiek (huiselijk geweld, alcoholgebruik). Sociale overerving leidde er onder andere toe dat deze patronen in stand werden gehouden: 'Wij Limburgers treuren collectief om de mijnsluiting. Ook de derde generatie die nooit een mijn van binnen heeft gezien - daarmee wordt het denken in stand gehouden: wat óns is aangedaan ...' [stakeholder 21; socioloog]

In Genk en Eindhoven daarentegen hebben overheid en private partijen na sluiting van de grote (mijn)industrie succesvol ingespeeld op de economische dynamiek: 'De mijngebouwen in Genk worden tegenwoordig gebruikt als kunstfaculteit en er zijn een bioscoop en een fietsenmaker gevestigd. Daarmee worden een nieuwe cultuur en uitstraling gecreëerd. Jongeren vinden dat je daar dus iets kunt doen en dat je niet weg hoeft, en dat het daar the place to be is.' [stakeholder 21; socioloog]

In de Belgische Kempen, met name in Vlaanderen, bleek meer ondernemingszin te bestaan en zijn veel kleine en middelgrote ondernemingen (KMO's/MKB's) opgezet. In Zuid-Limburg, net als in Wallonië, bleef men vooral vasthouden aan loonarbeid en was er onder inwoners minder ondernemerszin.

De voormalige mijngebieden veranderden veelal van een aantrekkingsgebied in een afstotingsgebied, mede door het negatieve imago van een herstructureringsgebied.

\section{Gezondheidsvaardigheden}

Stakeholders noemen beperkte gezondheidsvaardigheden van mensen met een laag opleidingsniveau als een mogelijke verklaring voor een slechtere gezondheidssituatie. Wanneer mensen niet weten hoe ze toegang tot preventie, zorg of andere voorzieningen moeten krijgen, heeft dit een negatieve invloed op hun gezondheid en het maken van gezonde keuzen: 'Je kunt wel goede preventievoorzieningen hebben, bijvoorbeeld ten aanzien van vaccinaties, maar of het werkt is afhankelijk van of de informatie over het bestaan en het belang van het systeem de inwoners bereikt.' [stakeholder 5; onderzoeker]. 'Er wordt onvoldoende gebruikgemaakt van preventieve gezondheidszorgvoorzieningen. Daarbij spelen laaggeletterdheid en lage gezondheidsvaardigheden een grote rol.' [stakeholder 2; afdelingshoofd]

Mensen met een lagere opleiding/SES en mensen met een migratieachtergrond hebben vaker minder gezondheidsvaardigheden en zijn moeilijker te bereiken met gezondheidsinformatie. Als deze groepen oververtegenwoordigd zijn, zoals in de Provincie Luik, resulteert dat in gezondheidsverschillen met regio's waar deze groepen ondervertegenwoordigd zijn. 


\section{Grensbarrières}

De grens wordt als een barrière ervaren en er wordt niet naar mogelijkheden over de grens gekeken. Ieder land heeft eigen wet- en regelgeving. Hierdoor kan het ingewikkeld zijn om over de grenzen te gaan studeren, werken of wonen. Ook ervaren mensen grenzen ten aanzien van cultuur, omgangsvormen en vooral taal: 'Door nationale wet- en regelgeving, studiebeurzen, belastingen, uitkeringen en sociale premies kan het complex worden om te kijken naar mogelijkheden over de grens.' [stakeholder 13; directeur]

Zonder grensbarrières kunnen de afzonderlijke regio's meer profiteren van de mogelijkheden in hun grensoverschrijdende omgeving: 'We maken allemaal onderdeel uit van meerdere systemen: Zuid-Limburg, Limburg, Nederland, de EMR, Europa en de wereld. Afhankelijk van de sociale- en gezondheidsuitdagingen worden het gezondheidssysteem en de partners bepaald. Daarbij moeten we het "grensdenken" loslaten. We hebben zelf een lijntje op de kaart getekend.' [stakeholder 6; directeur]

Oost-België wordt door de stakeholder als voorbeeld genoemd. Door de beperkte omvang van deze regio en de ligging tussen het Franstalige Wallonië en de Duitse grensregio is het voor inwoners van OostBelgië min of meer vanzelfsprekend om de buurtalen te spreken. Uit cijfers blijkt dat bijna 13.000 werknemers uit Oost-België in Wallonië, Duitsland of Luxemburg werken. Omgekeerd pendelen ook meer dan 6.000 mensen naar Oost-België [10]. De grensbarrière van de taal speelt hier vrijwel geen rol, en vanwege de beperkte voorzieningen en werkgelegenheid zijn ze min of meer genoodzaakt om letterlijk en figuurlijk de grenzen op te zoeken.

\section{Verbetermogelijkheden}

\section{Integraal beleid}

Het integreren van gezondheid in alle beleidssectoren, ofwel Health in All Policies (HiAP), wordt door meerdere stakeholders genoemd als een belangrijke stap in het verbeteren van de gezondheidssituatie. HiAP betekent dat in beleidsbeslissingen, ongeacht de beleidssector, de mogelijke impact ervan op gezondheid wordt meegewogen [11]. Het gaat vooral om beleidsbeslissingen die samenhangen met ons dagelijks leven, zoals leefomgeving, wonen, werken, onderwijs en vrije tijd. De beleidssectoren arbeid en onderwijs worden als meest kansrijk genoemd: 'Je moet juist ook de mensen betrekken die nu nog niet zijn betrokken, maar die wel de meeste invloed op gezondheid hebben: milieu, stadsplanning, verkeer, toerisme.' [stakeholder 4; coördinator]. 'Transversaal denken en een aanpak vanuit de levenscyclus en bijbehorende settingen zijn van belang; onderwijs, werk, ruimtelijke ordening. Hoe gaan we daarop inspelen? Met Health in All Policies, zoals in Wales.' [stakeholder 7; coördinator]
Voor versterking van gezondheidsvaardigheden ligt de sleutel ook bij integraal beleid, namelijk gezondheid onderdeel maken van het onderwijs. Onderwijs vormt naast de opvoeding de basis voor de verdere levensloop van een individu: 'Omdat onderwijs, naast opvoeding, de basis vormt voor de verdere levensloop van een individu, ligt dáár de sleutel. Het vroeg aanleren van bijvoorbeeld zelfcontrole is van invloed op hoe je omgaat met leefstijlfactoren. Gezondheidsvaardigheden gaan ook over kennis van gezondheid en het maken van gezonde keuzen.' [stakeholder 22; onderzoeker/ afdelingshoofd]

\section{Beschouwing}

Dit onderzoek toont aan dat er verschillen zijn in de gezondheidssituatie binnen de EMR-regio's. Belgisch Limburg heeft binnen de EMR de gunstigste gezondheidssituatie. In Zuid-Limburg en Regio Aken (D) is de gezondheidssituatie minder gunstig en de Provincie Luik (B) scoort het slechtst. Er zijn zowel verschillen tussen de EMR-regio's, als binnen elke regio.

In algemene zin blijkt dat generieke en specifieke maatregelen een belangrijke rol spelen in de verschillen in de gezondheidssituatie in de EMR. Vanuit historisch oogpunt heeft het sluiten van de mijnbouw en industrieën een belangrijke stempel gedrukt op de huidige situatie in deze regio's, die gekenmerkt wordt door een verhoogde werkloosheid (met name in de Provincie Luik (B)). Terwijl de ene regio een positieve wending heeft weten te geven aan de sluiting van de (mijn)industrie, sijpelen in de andere regio de negatieve gevolgen daarvan nog door tot in de huidige generatie. Zo trekken al jaren hoger opgeleide jongeren weg uit de regio Zuid-Limburg vanwege een gebrek aan passende werkgelegenheid [12].

Verder wordt de grensligging als een factor genoemd die een nadelige invloed kan hebben op de gezondheidsachterstand. De carrièrekansen van inwoners van grensregio's en de omvang en diversiteit aan voorzieningen die ze tot hun beschikking hebben, zijn over het algemeen kleiner dan in regio's zonder grensbarrières. Zo lijkt vooral Zuid-Limburg (NL) minder aantrekkelijk voor hoogopgeleiden, waardoor deze regio in vergelijking met het eigen achterland een relatief laag opgeleide populatie heeft [1]. De EMR wordt in uiteenlopende mate gekenmerkt door een lage SES-populatie. Een lage SES hangt samen met een ongezondere leefstijl en beperktere gezondheidsvaardigheden [13]. Deze resulteren in gezondheidsachterstanden, die door intergenerationele mechanismen (sociale overerving) in stand worden gehouden [14].

HiAP vestigt de aandacht op het meewegen van de gezondheidsimpact in overheidsbeslissingen buiten de gezondheidssector, bijvoorbeeld het meewegen van de gevolgen voor de gezondheid van de aanleg van een luchthaven of snelweg, of het afgeven van een vergunning voor een casino [9]. Wales was 
een van de eerste gebieden in de wereld waarin een Health Impact Assessment (HIA) wettelijk verplicht werd. Met een HIA brengt men de gezondheidseffecten van het voorgestelde beleid in kaart, zodat deze meegewogen kunnen worden in de besluitvorming, met als uiteindelijk doel de gezondheid zo veel mogelijk te maximaliseren [15]. In Zuid-Limburg (NL), waar sprake is van een hardnekkige gezondheidsachterstand, probeert men deze in te lopen door bij zwangerschap en geboorte ook de sociale factoren mee te nemen, zoals armoede, schulden of slechte huisvesting. Daarnaast wordt gezondheid een belangrijker onderdeel van de opvoedingsondersteuning, het onderwijsbeleid, het arbeidsmarktbeleid en het omgevingsbeleid [16]. De levensloop vormt hierbij het uitgangspunt. De meeste gezondheidswinst is immers te behalen aan het begin van de levensloop vanaf de (pre)conceptie tot achttien jaar -, met extra aandacht voor degenen met de grootste gezondheidsachterstand, zoals mensen met een lage SES [17]. Het Zuid-Limburgse beleid is een voorbeeld van HiAP vanaf het prilste begin van de levensloop.

Vooral op de beleidsterreinen onderwijs, arbeid en omgeving kunnen de EMR-landen nog veel van elkaar leren als ze meer gezamenlijk optrekken bij het opstellen van HIA's. Zo zijn er bijvoorbeeld grote verschillen in schooltijden en gezonde school-concepten, waarbij het de vraag is of deze impact hebben op de gezondheid. Het vergroten van carrière- en arbeidskansen over grenzen heen kan een gunstige impact hebben op de gezondheid, maar dat is tot dusver niet in kaart gebracht. Een luchthaven in Luik maakt gebruik van het Nederlands luchtruim; welke impact heeft dat op de gezondheid van de bevolking in de grensregio? Kortom, met HiAP en de daaraan gekoppelde HIA kunnen de grensregio's nog grote verbeterslagen maken.

Het gebruik van een mixed method-opzet leverde niet alleen objectieve data op, maar gaf ook inzicht in verklaringen voor de gevonden patronen in de gezondheidssituatie. In het ideale geval was de grensoverschrijdende vergelijking van de gezondheidssituatie met meerdere indicatoren in kaart gebracht (denk aan aanvullende leefstijlindicatoren of data omtrent zorggebruik). Daarnaast was niet elke indicator voor elke afzonderlijke EMR-regio beschikbaar, zoals de BMI, wat vergelijken bemoeilijkte. Hoewel de huidige analyse een goede eerste inschatting geeft, is verdere samenwerking tussen de EMR-regio's op het gebied van dataverzameling nodig om een rijkere dataset voor grensoverschrijdende vergelijking van de gezondheidssituatie mogelijk te maken. Deze visie wordt gedeeld door de Euregionale partners. In de Euregionale projecten 'Data in de EMR', 'Social Norms Approach' en 'Youth Euregional Survey' wordt daarom op basis van de inzichten uit dit onderzoek verder gewerkt aan een grotere en structurele beschikbaarheid van data in de EMR.
Er is met een beperkt aantal stakeholders gesproken. Voor verder onderzoek en een beter beeld van de gezondheidsverschillen zijn ook experts nodig uit het onderwijsveld, de private sector (bedrijven) en de bevolking. De Euregionale contacten die zijn gelegd en het netwerk dat is opgebouwd, bieden kansen voor diepgravender onderzoek.

Raadpleeg het volledige rapport via: https://www. ggdzl.nl/fileadmin/files/ggdzl/Documenten/ Euregiofactor/Op_zoek_naar_de_Euregio-factor.pdf.

Open Access This article is licensed under a Creative Commons Attribution 4.0 International License, which permits use, sharing, adaptation, distribution and reproduction in any medium or format, as long as you give appropriate credit to the original author(s) and the source, provide a link to the Creative Commons licence, and indicate if changes were made. The images or other third party material in this article are included in the article's Creative Commons licence, unless indicated otherwise in a credit line to the material. If material is not included in the article's Creative Commons licence and your intended use is not permitted by statutory regulation or exceeds the permitted use, you will need to obtain permission directly from the copyright holder. To view a copy of this licence, visit http://creativecommons. org/licenses/by/4.0/.

\section{Literatuur}

1. Jansen M, Kuppens E. Op zoek naar de Limburg-factor: wat is er bekend over de gezondheidsachterstand van Limburg ten opzichte van de rest van Nederland, welke kennis ontbreekt nog en hoe komen we tot een trendbreuk? Maastricht: GGDZuid Limburg; 2015.

2. Creswell JW, Clark VL, Gutmann ML, Hanson WE. Advanced mixed methods research designs. In: Tashakkori A, Teddlie C, redactie. Handbook of mixed methods in social and behavioural research. Thousand Oaks: SAGE; 2003. pp. 209-40.

3. Boeije H. Analyseren in kwalitatief onderzoek. Denken en doen. Den Haag: Boom Lemma uitgevers; 2014.

4. euPrevent|EMR, GGD Zuid Limburg, Centraal Bureau voor de Statistiek. Data voor een positieve gezondheid in de EMR. 2018.

5. Curvers N, Willems L. Op zoek naar de Euregio-factor. Maastricht: GGDZuid Limburg;2018.

6. International Labour Organization. Resolution concerning statistics of work, employment andlabourunderutilization. Genève: ILO; 2013.

7. Unesco Institute for Statistics. International Standard Classification ofEducation-ISCED2011. Montreal: Unesco Institute for Statistics; 2012.

8. WHO-FIC. Internationale statistische classificatie van ziekten en met gezondheid verband houdende problemen. Houten: Bohn Stafleu van Loghum; 2014.

9. Centraal Bureau voor de Statistiek. Beknopte methodebeschrijving gezonde levensverwachting. band 2018. Den Haag: CBS; 2018.

10. Ministerie van de Duitstalige Gemeenschap van België. Ostbelgien in cijfers. Stand 2018. Eupen: Ministerie van de Duitstalige Gemeenschap van België; 2018.

11. Government of South Australia \& World Health Organization. Progressing the sustainable development goals through health in all policies: case studies from around the world. Adelaide: Government of South Australia; 2017. 


\section{Wetenschappelijk artikel}

12. Cörvers F. Krimpen zonder kramp: over demografische transitie en regionale arbeidsmarkten. Maastricht: Universiteit Maastricht; 2014.

13. Werfhorst $\mathrm{H}$ van de. Een kloof van alle tijden. Verschillen tussen lager en hoger opgeleiden in werk, cultuur en politiek. Amsterdam: Amsterdam University Press; 2015.

14. Larson K, et al. Health disparities: a life course health development perspective and future research directions. In: Halfon N, Forrest C, Lerner R, Faustman E, redactie. Handbook of Life Course Health Development. Basel: Springer;2018. pp.499-520.
15. Owen R. Wales is leading the world with its new public healthlaw. London: The Conversation; 2017.

16. Zuid-Limburgse gemeenten. Zuid springt eruit. ZuidLimburg zet nieuwe trend in gezondheid. Maastricht: ZuidLimburgsegemeenten; 2019.

17. Broeders DWJ, Das HD, Jennissen RPW, Tiemeijer WL, Visser $\mathrm{M}$ de. Van verschil naar potentieel: een realistisch perspectief op de sociaaleconomische gezondheidsverschillen. WRR-Policy Brief 7. Den Haag: WRR;2018. 